Copyright $(2016$ SBPjor / Associação Brasileira de Pesquisadores em Jornalismo
BETWEEN A NEW

ARCHITECTURE AND THE

REAFFIRMING OF HEGEMONIC POWER STRUCTURES:

Veja's Portal coverage of the establishment of BRICS (2005-2010)

IVAN BOMFIM

Universidade do Vale do Rio dos Sinos, Brazil

\begin{abstract}
Given the paradigm shift of the Brazilian Foreign Policy implemented in the government of Luiz Inácio Lula da Silva, this article analyzes the news coverage of the Veja portal in regards to the establishment of the BRICS group between the years 2005 and 2010. We understand the internal and external political spheres as imbricated, and the journalism that focuses on the external action of the state participates in this configuration by giving visibility to certain discourses. In order to achieve our goal we have combined the critical and the French discourse analysis.
\end{abstract}

Keywords: BRICS. Foreign policy. Veja Portal. Discourse Analysis. South-South Coalition.

\title{
ENTRE UMA NOVA ARQUITETURA E A REAFIRMAÇÃO \\ DAS ESTRUTURAS DE PODER HEGEMÔNICAS: a cobertura do portal Veja sobre a constituição dos BRICS (2005-2010)
}

RESUMO - Tendo em vista a mudança paradigmática da Política Externa Brasileira implementada no governo de Luiz Inácio Lula da Silva, este artigo analisa a cobertura noticiosa do portal Veja sobre a constituição do grupo BRICS entre os anos de 2005 e 2010. Entendem-se as esferas políticas interna e externa como imbricadas, e o jornalismo que enfoca a atuação externa do Estado participa desta configuração ao dar visibilidade a determinados discursos. Para a consecução da investigação, utiliza-se uma conjunção das análises de discurso crítica e francesa.

Palavras-chave: BRICS. Política externa. Portal Veja. Análise de Discurso. Coalizão Sul-Sul 


\section{ENTRE UNA NUEVA ARQUITECTURA DEL PODER Y LA REAFIRMACIÓN DE LAS ESTRUCTURAS DE PODER HEGEMÓNICAS: \\ la cobertura del portal Veja sobre el establecimiento de los BRICS (2005-2010)}

RESUMEN - Dado el cambio de paradigma de la Política Exterior de Brasil implementado en el gobierno de Luiz Inácio Lula da Silva, este artículo analiza la cobertura del portal de noticias Veja acerca del establecimiento del grupo BRICS entre los años 2005 y 2010. Se entiende como imbricadas las esferas políticas internas y externa, y el periodismo que se centra en el estado de actuación exterior participa en esta configuración dando visibilidad a ciertos discursos. Para el logro de la investigación, se utiliza una combinación de análisis del discurso francés y crítico.

Palabras-clave: BRICS. Política exterior. Portal de noticias Veja. Análisis del Discurso. Coalición Sur-Sur

The social role of the journalistic fiel

The analysis of the emergence and of the first institutionalization measures of the BRICS group stems from the coverage made by the Veja portal leads to a consideration of the relationship between journalism practice and the degree of contact between States. In another study (BOMFIM, 2012), I indicated that the shared origin between studies of Journalism newsmaking and the social constructivist theory of International Relations stemming from the Sociology of Knowledge developed by Berger and Luckmann (1973) allows us to understand international journalism as a space of interaction between the two fields. However, the question we pose here is to understand how the news about the composition of an inter conjunction mobilizes external and internal dimensions of the state. The definition of international journalism does not cover topic in its entirety, since the news have a significant domestic dimension, being reflected precisely by the structuring of ideas about foreign policy.

The Journalistic supremacy of narrating reality, based 
on the use of symbolic power (BOURDIEU, 1989), is reflected in the very structure of its condition of reality. To speak reality is to precede a statement about it and about itself, and journalism reaffirms the values and beliefs upon which it stabilizes itself. The conformation of the objective power relations as a replication of relations of symbolic power is latent, and the possibility to enunciate corresponds to a form of struggle, even more so when it disputes the orientation of meanings to the level of common sense. As an expert-system (MIGUEL, 1999), Journalism is awarded a strategic role based on the social belief of its legitimacy to narrate the world. It is also a form of knowledge, as states by Meditsch (1997). Lacking scientific rigor and without identifying itself as to common sense, Journalism constructs a different type of knowledge - "about something". While appreciating what is seen as singular, it denies particular and universal qualities, and the empiricist attitude of "searching for facts" it indicates reality as devoid of threads and historical or dialectical connections.

The questions of enunciative authority and of the knowledge produced by Journalism are further highlighted with respect to issues involving dynamic territorially distant from the everyday experience of individuals. According to Teasing (2000), news involving the international scenario can be considered to have a pedagogical bias, often being the only layer of information that the public will have about distant realities. It is invested in the search for elements recognizable to the public, which is reflected in the composition of stereotypical typifications. These representations are not neutral: they are constituted in ideological structures, which establish levels of understanding of the objects (such as social groups) in order to promote specific social conformations, notes Biroli (2011). In the news on foreign policy, one of the effects of this situation is the composition of homogenizing and Manichean representations: Developed and underdeveloped countries, exotic (from which the pair "not exotic" is not named), modern and backward, etc. Such definitions influence the ways of conceiving the world, being used by different groups in the domestic debate about the definition of the establishment of close relations to other countries. 


\section{The relationship between journalism an foreign policy}

Within the logic of the political domain, the symbolic aspects of the conformations can be understood as "subjective", in contrast to the nature of "objective" decisions that politics pursues. However, for Bourdieu (1989), it is precisely in structuring the symbolic power that political power may be exercised. Whether to allow greater knowledge and social deliberation or to persuade and influence the political field, the political field sees the journalistic field a way of trying to achieve or exercise power. On the other hand, the greatest influence of the journalistic field over the political is discoverable in the production of political capital from the effects of visibility (entrance on the public stage). Members of the political system seek the journalistic field to meet three main requirements: visibility, image building and legibility of its political plan. As Miguel (2002, p 163), states, access to the media structure is "the main dissemination tool of worldviews and political projects; [...] is the space where they are exposed to the various representations of the social world, associated with the various groups and interests present in society". In democratic regimes, the necessary exposure to discourses of the groups that make up the political spectrum passes through the sphere of visibility composed by the media.

The situation is no different with regard to matters relating to the external action of the state. Putnam (1988) states that to think of foreign policy as independent of internal determinations is to make a mistake. He posits the concept of Two-Level Games to address the interweaving relationship between the internal and external political dimensions in the formulation of international operations. A continuum discussion is established between Level I (international relations) and Level II (domestic debate on foreign operations), with inter-state action being defined by the "decision makers" - in Brazil, the Ministry of Foreign Affairs. The groups that try to influence the course of foreign policy must operate within mediations between citizens and government, in order to legitimate its political demands. The media sphere serves as a place of influence for foreign policy through making the discourse of interest groups exotic, an act that that Rodrigues (2002) delegates to Journalism which provides visibility and legibility to reappropriate, in the news, certain gestated and/or mobilized interpretations in other domains. Along these lines, Milner (2007) understands journalism as an actor 
in the dynamic foreign policy allocated in the category "social interest group", pressing the state to adopt its prerogatives. In times of crisis, this pressure becomes more visible, since there is an increase in the general interest in foreign affairs.

The relationship between Journalism and foreign policy encompasses the public opinion sphere, of the establishment of the debate on external choices by the government, involving conviction (persuasion) about usually distant subjects of day-to-day experiences. The institution of common sense over a complex agenda is one of the objectives of the internal political circles that target interests internationally.

\section{Brazilian foreign policy elements and the establishment of BRICS}

Foreign policy is a prerogative of the State. In Brazil, we simplistically agree that diplomats apply the provisions set by the Executive branch, and having the Legislative as an oversight body for example, ratifying or not agreements. As a branch of the Executive power, diplomats have agency defined by parameters that refer to the foreign policy line followed by the country. The goals are set in a complex way, with interest groups pushing for its deliberations to be taken into account. These groups disrupt the composition of the demands scenario, representing national and international companies, non-governmental organizations and think tanks, who produce knowledge about specific subjects or general issues in an attempt to propagate their views of the issues.

Besides the obvious sovereign existence, cyclical or dynamic factors set the formation of the international integration objective of the state. Cervo (2008) maintains that the role of Brazilian foreign policy (or PEB) is guided by standards that led to a set of assumptions, the overall history of Brazilian diplomacy². Since the 1930s, the main vector of national foreign policy is the issue of economic development. This is "the leitmotif and the true fulcrum of national ideology" (ALMEIDA, 2006, p. 179), was seen as a way of overcoming dependence and backwardness in regards to the geopolitical North, stemming from measures to promote modernization. The various views on development are crystallized in the mainstream diplomatic national fronts: associacionistics and independentist. The first advocate to be 
linked the prerogatives dictated by world powers, especially the US. The second group sees no prior alignment to the Northern countries the most legitimate way to undertake foreign policy.

The emergence of the BRICS should be understood within the framework of an axiomatic change in the direction of the PEB in the change from Fernando Henrique Cardoso's government (19952002) to that of Luiz Inácio Lula da Silva (2003-2010). According to Cervo (2008; 2010), the neoliberal paradigm with the associationistic character is abandoned for the return to the independentist worldview, embodied in the logistics paradigm. Vigevani and Cepaluni (2007) corroborate this view and show that multilateralism gained prominence in the Lula period. On the economic front, Brazil has sought to participate in the setting of a new multipolar order to defend the interests of the South and strengthen agreements, finding support in the preservation of the established regulations and aiming to modify those that do not follow egalitarian principles. This is a different scenario from the 1990s, when the Brazilian government avoided friction with the US and the European Union.

The dedication that Brazilian diplomacy focuses towards multilateral discussions is consistent with the possibilities of that country. Lacking enforcement - military force - the decisions are a combination of common goals to the various countries, and based on the moral value of the claims. Thus, the success with developing nations achieves greater compliance, promoting the South-South dialogue. Brazil has importance both historically and conjecturally in the international system, being considered a large peripheral or regional power. Positioning itself as an intermediary (between developed and developing countries, central and peripheral), the country increases its bargaining power in the interstate system.

The emergence of the term BRIC - since 2010, with the inclusion of South Africa, BRICS - is the institutionalization of an action among countries considered to be the major emerging powers of the twenty-first century. The group has its beginning in the acronym coined by the head of global economics department at Goldman Sachs, Jim O'Neill in 2001, in a text ${ }^{3}$ titled Building Better Global Economic BRICs. The articulations become intensified starting in 2005, and since 2009 annual summits have been held. The association brings together global and regional powers. In addition to economic strength, it is necessary to consider that Russia and China are permanent members of the UN Security (CS- 
UN) and that of the five countries, only South Africa and Brazil are not part of the "nuclear club" - do not have atomic devices, but they use nuclear technology for peaceful purposes. According to Cervo (2010), Vigevani and Cepaluni (2007) and Amorim (2008), Chancellor during that period, the BRICS group are a South-South integration initiative that questions the implicit established global hierarchy and one requires changes in this order.

\section{A critical constructionist analysis}

Journalistic activity is inseparable from the linguistic universe, though not reducible to a language operation. Whereas, according to Benetti (2007), one can see that journalism as a discourse, is based on "justified true belief", exposing the settings of the communication contract, concept coined by Charaudeau (2006). This argues that the communication processes are to be understood from the contractual metaphor involved implementing a tacit agreement, dependent on dialogic condition.

Stemming from the constructionist perspective, I borrow from Critical Discourse Analysis (CDA), An interdisciplinary model of the prerogative of language as a social practice, and borrowing from Fairclough $(2003,2005)$, which points out the overlaps between language and socio-political structures of power and domination, as well as from Van Dijk $(2001,2005)$, whose view can be considered sociocognitive. CDA constitutes the analysis of the ideological aspects and relations of power, in relation to discourses, interpreting the naturalization processes and its consequences in the systematic social interactions. The observation of contexts is demanded, extrapolating the textual scope to enlarge the angle of interpretation. Van Dijk (2005), the main CDA postulates are: 1) dedication to social problems; 2) power relations are discursive; 3) discourse constitutes society and culture; 4) discourse has an ideological function; 5) the link between text and society is mediated; 6) discourse analysis is interpretive and explanatory; 7) discourse is a form of social action.

CDA allows the merge to other research perspectives (VAN DIJK, 2005), under the pretext to examine the ways in which the production and reproduction of discourses that conform contextual situations of exploitation, hegemony and domination. So, make use of the concept of discursive formation, or FD (BENNETTI, 2008; 
PÊCHEUX, 1975), related to the French Discourse Analysis (FDA). A discursive formation is "that which, in a given ideological formation, that is, from a given position in a given situation, determined by the state of class struggle, determines what can and should be said" (PÊCHEUX, 1975, p. 160). Not existing within a closed structure, it operates from interdiscursivity. The discursive formations are "meaning regions", demarcating borders within the interpretive text with directions stemming from ideological conformations.

Ideology, as a world worldview, structures interpretive axes, making itself effective as evidence. However, we must observe the difference between CDA and FDA as the first sees no discourse as free from ideology, as it is a position taken on the reality that is expressed linguistically; in the second, ideology is related to forms of power and domination expressed discursively. According to Orlandi (2005), ideology processes an erasure of existence itself while concealing interpretation, presenting what is subjectively constituted as objective reality. Fairclough argues that ideology "is a cumulative and naturalized orientation that is built on standards and agreements, as well as a current work of naturalization and denaturalization of such guidelines in speech acts" (2001, p 119) and relates it to Gramsci's notion of hegemony.

The choice for this combination is based on the methodological provision to relate linguistic aspects relating to social externality and representation in domestic and foreign policy spheres. The attention given by the CDA context is related to the discursive materiality, and deems imperative to examine the process of paraphrasing (reiteration of meaning) textually instituted over five years in its interdiscursive crossings. The FDA allow us to examine the stabilization of meanings joint in the body, and from these we undertake an analysis in which the nuclear senses are related to socio-political dynamics demonstrated midiatically. To combine elements of the CDA and FDA serve to decomplexify strongly established systems, as the discursive dimension, as a social practice, supports and is supported by control structures of the micro-level to macro-social.

According to Fairclough (2003), discourse presents an articulated dialectical dimension in four stages: a) Emergency (the simplification of complex realities in discourses from the articulation of existing discourse elements); b) Hegemony; c) Recontextualizing (dissemination of discourse that cross social fields); d) operationalization (the influence of discourse in the processes of 
interaction and identification, materialized in the "physical world"). In the present research although not building a schematic analysis, I constitute an analysis seeking to understand the discursive framework stemming from the steps stated by the author.

\section{The Veja Portal}

To undertake the analysis of the material published by the Veja Portal, it is necessary to analyze the news vehicle at hand. According to Sabadini (2006), the portal was created in 1997, and initially reproduced what it published, and served as an archive of the printed versions of the magazine (launched in 1968). In 2000, they began producing exclusive news for the website and, in 2002, supplementary material to the material of the printed version of the magazine. Later, indicators to hyper links were also added to most of the material in the printed magazine. In 2012, access to all of the digitized collection of the magazine was made available.

Veja touts concepts of independence and control of political power substantiating itself in a strong image of legitimacy that the publication has built (BENETTI, 2007; BENETTI, HAGEN, 2010). By expressing opinions incisively, it grants itself the role to explain the reality in a totalizing way, placing events in political, economic, and cultural, etc., under the same ideological prism. This factor must be understood from the perspective of an editorial identity, which relates the production of the magazine to the Abril publisher's plans, the media group to which it belongs. Roberto Civita, founder of Abril, says of the group's mission:

Abril has been taking for the past 30 or 40 years the path of a market economy, the opening of borders, the globalization of the free enterprise. The role of the press is not to work in the backstage or to get to X minister and to pressure him: but rather to present things to the reader, trying to change the minds of people on its pages and not in their offices (MIRA, 2001, p. 78).

Over the past decades, Veja established itself as a representative in the national journalistic universe, the binomial economic liberalism / political conservatism, ideologically expressed by neoliberalism. The public that accesses the website - according to information from April - is mostly composed of individuals stemming from social classes A and B (77\%) of which $66 \%$ are men and $34 \%$ 
women. During the Lula administration (2003-2010), a period that encompasses the creation and institutionalization of BRICS, Veja positions itself openly in opposition to the government order, particularly during the second term of President. The critical stance is related in particular to the socioeconomic policies of redistributive nature and the representatives of the so-called radical wing of the Workers Party. Significantly, the company sees the members of these groups as the representation of socialist ideologies matrix, which it has historically been a fierce opposition. It is no wonder that the Abril group has umbilical relations with Instituto Millenium ${ }^{4}$, a think tank that seeks to spread neoliberal precepts.

\section{Methodology: from macro propositions to discursive formations}

The body of the research consists of 32 news articles, published between October 18, 2005 and December 24, 2010, involving the BRICS group. I proceeded to the analysis of the material seeking to synthesize the meanings found in each textual fragment in the form of topics or according to Van Dijk's (2005), denomination of macro propositions. As an example of the operationalization, I expose the macro propositions $(M)$ constituted in examining the story Bric: Brazil finally reaches colleagues (Veja, 2008):

M1: Brazil finally reaches the other Bric countries according to The Wall Street Journal

M2: Brazil was considered the "black sheep" of the group

M3: The Explanation is the strength of the Real, due to inflow of foreign investments

M4: Brazil is still far from China, but the margin of the Chinese economic expansion is smaller

M5: Brazil has reached a more mature stage of development than China and India

The conformation of the meanings frame synthesized in each text enables the mapping of nuclear meanings in the face of the investigated themes. I have outlined seven key discursive formations (DF); areas of meaning that delineate interpretations in the interdiscursive space: 
DF1 - BRICS was created by a private financial institution

DF2 - China is the leader of the BRICS group

DF3 - Brazil is the weakest of the BRICS group

DF4 - Brazil is gaining economic strength

DF5 - BRICS should only be an economic group

DF6 - BRICS are important to the world economy

DF7 - BRICS seek global influence

Temporally, most of the original texts is characterized as a bunch of scattered notes, reporting on economic indicators that sometimes show up as contradictory. We note a division in the formation of the corpus: a significant amount of news is dedicated to the use of the BRICS countries as a comparison for instance, Brazilian economic results, while another set of texts focuses on the institutionalization and promotion activities of the group. With the holding of annual summits between the leaders of countries from 2009 , relations are narrowed with motivations that go beyond the initial economic goals.

\section{The hegemony BRICS's financist design}

The DF1, which is the one with the greatest exposure - BRICS was created by a private financial institution - has a "technical" matrix, reiterating, throughout the temporal frame, the origin of the group under the acronym in question. Quantitatively, the macro propositions related to it are present in ten texts, about one-third (32\%) of the total. However, beyond the percentage aspect, what stands out as the greatest impact is its hegemonic condition: It is from the membership statement of the BRICS group to a financist logic that the basic interpretive axes are structured, as the statement regarding Chinese superiority, the criticism regarding Brazil's performance and subsequent conclusion of its strengthening, and the argument that the block should only focus on issues of economic context.

We can infer implications from an article published in 2010, in which it is stated that the bloc "was established in 2001 by the head of global economics department at Goldman Sachs, Jim O'Neill" (VEJA, 2010a). Since being "invented" by Goldman Sachs, the association would get a predetermination of origin - which supposedly allows O'Neill, in that same text, to say what they should or should not do to 
the group to the participating countries, materializing the intention to "resume reins/control" on the bloc's guidelines even after the BRICS group had headed to other areas of action.

\begin{abstract}
VEJA: What are the main challenges for Brazil in the coming years?

O'NEILL: I believe that Brazil has very interesting challenges after this election. The future ruler must maintain efforts to keep inflation on target. I actually highlight the fact that the country has had for over a decade a fantastic economic policy, whose success is precisely due to fundamental reforms that were carried out in the period. The greatest credit must be given to former president Fernando Henrique Cardoso, but also, of course, to Lula's government. Something that, incidentally, strongly endorses the credibility of the current president is the fact of not having changed the course of things, when everyone was betting that he would.

However, the weight of the Brazilian State is very large and such a situation should not be maintained indefinitely. The country also has to engage more in the markets for its goods and services, going beyond commodities.

VEJA: Brazil is a country that has a historical difficulty of having a long-term promotion and export diversification policy. What can we do in addition to commodities, as you have recommended?

O'NEILL: Brazil has to keep trying and has to push itself even harder. Conquering international markets is not easy for anyone. There is much evidence in international trade that we need to pursue very high growth rates of productivity, which the Chinese demonstrate especially well. The key is productivity (VEJA, 2010a, our emphasis).
\end{abstract}

The emergence of this core sense is the concatenation of discourses such as the emptying of the actions of Lula's government, relating to the administration of Fernando Henrique Cardoso the success of the Brazilian economy in the period 2005-2010. Ironically, it would be possible to deduce that the economy has recovered in a magical way from the induced panic situation and stagnation in the beginning of the last decade, when a speculative wave attributed to the "Lula effect" (possibility of his election) was reflected as the sharp increase in the price of the dollar. By saying that "the State's weight is still very large," O'Neill reiterates the need for economic liberalization, suggesting the reduction of public control regarding points not mentioned. The meanings point to the discourse of state inefficiency, which is undermines the possibilities of development, with the addition of the phrase - "and such a situation should not be maintained indefinitely" - delineating the line of action to be undertaken. For the O'Neill oracle, it comes down to "productivity."

The DF2, which highlights the Chinese leadership is established by macro propositions in seven texts (21.87\%) and structured in 
conjunction with the two major approaches cited. According to the premises of the first, the achievements of China's economy become utopian topos that Brazil should aspire to, but is unable to achieve, particularly for the reasons highlighted by the meanings of DF3. An exemplary discursive sequence is found in the article understand the formation of the Bric/ Entenda a formação do Bric: "When the group was created, there was a greater homogeneity among countries. However, over time, the differences have increased, mainly from China when compared to other countries "(Jeja, 2010). In the second scenario, the preponderance is exposed by the ideas of a player's overall global interests that do not want to break the system as the largest holder of securities of US debt, while having action strategies in Africa and Latin America, and, as a member of CS-UN, have coercive power which Brazil does not have.

With macro propositions present in five articles (15.62\%), the DF3 aggregates Brazil's meaning of weakness - Brazil's GDP is the worst of Brics/ PIB do Brasil é o pior dos Brics (VEJA, 2009) is both a headline and discursive sequence. The FD4 indicates the strengthening of the country, but is not opposed to DF3, since it is based only on economic themes. The view of a weak economy ends up being affected by claims of economic growth with greater exposure to the end of the article, and the themes move toward the questioning of the institutions that govern the world system. The meanings that make DF6 and DF7 have constant interaction with the articles reporting that the block claims greater global influence. DF2 again has an important role, being the only outlined discursive formation on the overall representativeness of the BRICS - the Brazilian, Russian and Indian States, do not appear to be integrated into the international agenda such as China's, strengthening the formulation of speeches DF5.

\section{Brazil: BRICS's black sheep}

The predominance of the core discursive financist origin of the BRICS (DF1), Chinese leadership (DF2) and Brazilian inferiority in the block (DF3) is established from some nodal discourses, supported by the abolition of sociopolitical perspectives and the realization of economic and financial bias contextualizating reality. This preponderance leads to forged stereotypes in the capitalist logic 
and values, and the "clash" between the Chinese efficiency and the Brazilian constantly represented.

The analysis of China's the economic indicators is based on the essentialization of competence, which does not allow to question the ways in which this success is achieved: the base that sustains the Chinese model - a combination of cheap laborexploitation, violations against human rights, few labor rights, strong control over political activities, etc. - is concealed due to the success derived from efficiency. The term becomes a point of comparison (the articles point out the negative results of the country in relation to GDP growth, productivity and the Brazilian state size).

The idea of Brazil's inefficiency is undermined with the approval of their economic results. The design of the country ceasing to be the "black sheep" of the BRICS, exposed in Bric: Brasil enfim alcança colegas/ Bric: Brazil finally reaches colleagues (VEJA, 2008) It is based on confirmation of the predictions of economic growth attributed by financial institutions. A black sheep is the deviant individual who refuses to follow the established rules and does not comply with the outlook predicted for him. To Veja, by not keeping up with Russia, India, and China, Brazilians ran the risk of being excluded from BRICS. We must consider whether such an exclusion, brought by private bodies (such as investment banks and the press), would impact the institutional conformation of the group, considering that the article in question dates from 2008, one year prior to the first summit.

\section{BRICS as a "threat" to the international system}

Despite the largely focused approach towards the economic scope, the coverage shows evidence for the reflection about the world power architecture transformation. The DF2 (Chinese leadership) is both supported by the strength of their rates of economic growth and the expansion of its global power. Some of the articles referring to Russia highlight its huge military arsenal, highlighting the production as well as arms trade with other nations. It is difficult to understand the constitution of the BRICS outside the political realm, even as the group's institutionalization affirms an independent vision on the 
global stage. In five years, there were several moments that represent this perspective, such as seeking the support of Russia and China (permanent members of the UN-CS) to Brazil's role in the Iranian nuclear crisis in 2010.

The situation stems in response to countries that occupy leadership in the system. This can be seen in the article that deals with the possibility of the decline of US hegemony in the world, not only in economic sense, stemming from a report by the National Intelligence Council. Here are the closing paragraphs:

Brics - In this new multipolar system, emerging economies, especially China, India, Russia and Brazil, are seen as challenging the Americans. According to the report, if the members of the so-called Bric are up and coming, the European Union will only be a "jettisoned giant" since it could not transform its economic strength into military and diplomatic influence. With a greater number of power cores, the chance for conflicts to appear increases, evaluates the US document.

"Strategic rivalries should be around trade, investments and technological innovation, but one should not rule out a scenario such as the 19th century, with the arms race, territorial expansion and military rivalries. Types of conflict we do not see a long time, as the disputing natural resources, may rise again, " states the article. But NIC chairman, Thomas Fingar, warns: the chance to reduce the risk of conflict hereafter is in the hands of today's leaders (VEJA, 2008a, our emphasis).

The document alerts to a chaotic scene in which the multiplication of centers of power could lead to results such as an arms race and conflicts. There is a presupposed Pax Americana to be preserved, especially in the statement that says that the emerging economies are "challengers". There is a fear strategy at play: the analyst states that "types of conflicts that we have not seen in a long time, as the dispute over natural resources, may rise again." It is a fallacious statement because many contemporary wars were / are locked due to the interest in natural resources. The discourse of impending conflict between power cores - which rallies the nineteenth century events memories to compose threat - we can perceive a recontextualising movement, because it advocates free market as peacekeeping strategy. This combination of interests to creates a global justification for the conservation of the global status quo - even if part of the establishment has to undergo adaptations. 


\section{Towards a few final considerations}

Van Dijk (2005), understands social power in terms of control: groups have more or less power if they are able to establish more or less control over the attitudes and thoughts of members of other groups, causing non discursive effects - or operational in Fairclough's term (2003). The economistic discourse, identified with the liberal ideology that guides the editorial direction of the Veja portal seeks to interdict other ways of understanding the BRICS, since leaving the economic and financial sphere, the concert of forces in conjunction with the current international hierarchical environment. The advances that have been achieved are repeatedly analyzed within the logic of the current system, excluding the question of power structures, one of the main goals of the group.

Journalism is one of the main ways in which interest groups seek access to the mediatic visibility sphere to make public their conceptions of action and external objectives. In such disposition, the discourses that propose to be hegemonic, achieved social consensus. In the case of the coverage of BRICS the Veja portal between 2005 and 2010, the ideological praise consistent with the design of a single strand of thought linked to neoliberalism, and seeks to instill in the public's opinion from the target audience of the website, correlating meanings mobilized in the news and social and political implications.

The group in question, identified as the classes $A$ and $B$, with high economic power and a conservative profile, makes up a considerable part of the Brazilian political and economic elite. No wonder dialogism is sought in the use of the nodal discourse of efficiency, which sublimates other contextual issues (especially sociopolitical implications). To have an efficient economy becomes the goal of the Brazil's relations, and this quality is only achieved according to the portal's discourse through premises such as the growth of gross domestic product and increased foreign investment - without these indices being aimed towards social development. In other words, economic growth is not automatically related to improvements in people's lives, but is attached to the generation of income. Another example: it is stated at one point that Brazil is the "black sheep" of the block. The statement requires a solution that is forged from yearnings of the financial market, and fulfills the demands identified with the same logic. The website, while trying to discursively establish the economic efficiency parameters under 
neoliberal state as consensual, subjectively structures objectives references to be met by the country's actions abroad.

The essentialization of certain terms works for the aforementioned disposition, such as in the definition of emerging. Since not problematizing such definition, its acceptance is presupposed, in line with the values of the international system established by the hegemonic forces (US and EU). It is precisely the opposite of the goals reaffirmed officially by the BRICS, a South-South coalition. Its members advocate the need to reform the global structures in order to reflect new scenarios. Traditional forces, however, do not intend to make room for new poles, and the strengthening of neoliberal thinking is one way of maintaining the status quo as it asserts the primacy of leadership as intrinsic factor to the international system, while new powers are rejected as "threats to normalcy." The irruption of the BRICS is dynamically dubious: while at the same time they provide oxygen to the economic and financial sectors, shaken by the global crisis of 2008, they engender the questioning of the international political configuration.

I have observed here the ideological foundation of the coverage by the Veja Portal. The movement carried out from polyarchical understanding of the international environment is transmuted via discourse, in the affirmation of the rejected model. Thus, the articles, when the Brazilian economy shows itself weak, shows that the country is weak; when the economic sector is strengthened, only this domain is celebrated. It is as if the economy has become an independent entity of the state, while it is encouraged its domination over the designs to be followed by the national administration. Concurrently, at the domestic level, income redistribution actions are denied as a legitimate policy, being provided only to the productive efficiency in order to be put as an objective to be fulfilled, with this being negatively impacted by the "weight of the State". The critical response involves the attention to intrinsic interweaving of internal and external policies, so that the worldview of the "single thought" does not overlap the logic that served the institutionalization of BRICS. The new architecture of power must be consistent with new ways to conceive general sociopolitical issues, not reaffirm "certainties" that try to keep the block in the dependency sphere. And journalism is very important for a plural understanding of Brazil in the world.

* This paper was translated by Samantha Joyce 


\section{NOTES}

1 This paper presents part of the findings of the doctoral dissertation "The "megalomaniac" global player: Veja's portal view on Lula's government foreign policy", defended in 2015 in the Communication and Information Graduate Program at Universidade Federal do Rio Grande do Sul (PPGCOM-UFRGS).

2 a) Self-determination, non-intervention and peaceful settlement of disputes; b) legalism; c) normative Multilateralism; d) cooperative external action and non-confrontational; e) Strategic Partnerships; f) Realism and pragmatism; g) official cordiality with neighbors; h) Development as a vector; i) Independence of international integration

3 O'Neill's text can be accessed from the link http://www.goldmansachs.com/our-thinking/archive/archive-pdfs/build-better-brics.pdf.

4 Roberto Civita. Civita was part of the Câmara de mantenedores of the institute until his death in 2013.

\section{REFERENCES}

ALMEIDA, Paulo Roberto de. Relações Internacionais e política externa brasileira: história e sociologia da diplomacia brasileira. Porto Alegre: editora da UFRGS, 2006.

AMORIM, Celso. Os Brics e a reorganização do mundo. Tendências/ Debates, 08 de junho, 2008.

BENETTI, Marcia. A ironia como estratégia discursiva da revista Veja. Líbero (FACASPER), v. 20, p. 14-26, 2007.

BENETTI, Marcia. O jornalismo como gênero discursivo. Galáxia (PUCSP), V. 15, p. 13-28, 2008.

BENETTI, Marcia; HAGEN, Sean. Jornalismo e imagem de si: o discurso institucional das revistas semanais. Estudos em Jornalismo e Mídia (UFSC), v. 7, p. 123-135, 2010.

BERGER, Peter; LUCKMANN, Thomas. A construção social da realidade: tratado de Sociologia do Conhecimento. Petrópolis: Vozes, 1973.

BIROLI, Flávia. Mídia, tipificação e exercícios de poder: a reprodução dos estereótipos no discurso jornalístico. Revista Brasileira de Ciência 
Política: Brasília, n. 6, p. 71-98, julho/dezembro, 2011.

BOMFIM, Ivan. Construindo realidades: uma perspectiva de interação entre Jornalismo e Relações Internacionais. Comunicação \& Inovação, v. 13, p. 29-36, 2012.

BOURDIEU, Pierre. O poder simbólico. Lisboa: Difel, 1989.

CERVO, Amado. Inserção internacional: formação dos conceitos brasileiros. São Paulo: Saraiva, 2008.

CERVO, Amado. Brazil's Rise on the International Scene: Brazil and the World. Revista Brasileira de Política Internacional, Brasília, v. 53, p. 7-32, 2010.

CHARAUDEAU, Patrick. O discurso das mídias. São Paulo: Contexto, 2006.

FAIRCLOUGH, Norman. Discurso e mudança social. Brasília: Universidade de Brasília, 2001.

FAIRCLOUGH, Norman. Blair's contribution to elaborating a new doctrine of 'international community. Journal of Language and Politics, vol. 4, $n^{\circ} 1$, pp. 41-63(23), 2005.

MEDITSCH, Eduardo. O Jornalismo é uma forma de conhecimento. Biblioteca Online de Ciências da Comunicação, 1997.

MICUEL, Luis Felipe. O jornalismo como sistema perito. Tempo Social; Rev. Sociol. USP, S.Paulo, 11(1): 197-208, maio de 1999.

MICUEL, Luis Felipe. Os meios de comunicação e a prática política. Lua Nova, São Paulo, n.55-56, p. 155-184, 2002.

MILNER, Helen. Interests, institutions and Information: Domestic Politics and International Relations. Princeton, N.J.: Princeton University Press, 1997.

MIRA, Maria Celeste. O leitor e a banca de revistas. São Paulo: ed. Fapesp, 2001.

ORLANDI, Eni Pulcinelli. Análise de Discurso: princípios e procedimentos. Campinas: Pontes, 2005.

PÊCHEUX, Michel. Semântica e discurso. Campinas: Editora da Unicamp, 1975.

PUTNAM, Robert. Diplomacy and domestic politics: the logic of twolevel games. International Organization. Cambridge: Massachusetts Institute of Technology, 1988.

RODRIGUES, Adriano Duarte. "Delimitação, natureza e funções do discurso midiático". In: Porto, Sérgio Dayrell (Ed.). O jornal: da forma 
ao sentido. Brasília: Editora da UnB, 2002, p. 217-233.

VAN DIJK, Teun. Discourse, ideology and Context. Folia Linguistica, XXXV/1-2, $11-40,2001$.

VAN DIJK, Teun. Discurso, notícia e ideologia: estudos na Análise Crítica do Discurso. Porto: Campo das Letras, 2005.

VEJA, portal. Bric: Brasil enfim alcança colegas [http://veja.abril.com. $\mathrm{br} /$ noticia/brasil/bric-pais-enfim-alcanca-colegas/], 2008. Acessed: 12/09/2013.

VEJA, portal. EUA admitem: domínio no globo será menor até 2025 [http://veja.abril.com.br/noticia/mundo/eua-admitem-dominio-globosera-menor-2025/], 2008a. Acessed: 12/09/2013.

VEJA, portal. PIB do Brasil é o pior dos Brics. [http://veja.abril.com.br/ noticia/brasil/pib-brasil-pior-brics/], 2009. Acessed: 12/09/2013.

VEJA, portal. Entenda a formação do Bric, [http://veja.abril.com.br/ noticia/economia/entenda-formacao-bric/], 2010 . Acessed: 12/09/2013.

VEJA, portal. Bric precisa ter mais voz no mundo, diz O’Neill [http://veja. abril.com.br/noticia/economia/bric-ja-mais-importante-g7-diz-neill/], 2010a. Acessed: 12/09/2013.

VIGEVANI, Tullo; CEPALUNI, Gabriel. A Política Externa de Lula da Silva: a estratégia da autonomia pela diversificação. Contexto Internacional: Rio de Janeiro, vol. 29, n. 2, julho/dezembro 2007, p. 273-335.

Ivan Bomfim holds a PhD in Communication and Information from the Federal University of Rio Grande do Sul and is graduated in History from UFMG and Journalism from UNIBH. Currently he is special visiting researcher (postdoctoral studies) at the School of Creative Industry - Unisinos. 